\title{
Biopsja wargowych gruczołów ślinowych w diagnostyce zespołu Sjögrena — doświadczenia własne
}

\author{
Labial minor salivary gland biopsy in the diagnosis \\ of Sjögren syndrome - own experience \\ Katedra i Klinika Chirurgii Stomatologicznej i Periodontologii, \\ Uniwersytet Medyczny im. Karola Marcinkowskiego w Poznaniu
}

DOI: http://dx.doi.org/10.20883/df.2018.19

\begin{abstract}
STRESZCZENIE
Wstęp. Biopsja wargowych gruczołów ślinowych jest stosowana w diagnostyce zespołu Sjögrena (SS). Potwierdzenie mikroskopowe SS opiera się na stwierdzeniu występowania jednego lub więcej ognisk limfocytarnego zapalenia gruczołów (FSL) w przeliczeniu na $4 \mathrm{~mm}^{2}$ tkanki gruczołowej.

Cel. Celem pracy było przedstawienie własnych doświadczeń i rekomendacji w pobieraniu wargowych gruczołów ślinowych w zależności od kryteriów histologicznych, techniki chirurgicznej, komplikacji i użyteczności diagnostycznej.

Wnioski. Najbardziej rekomendowanym miejscem jest prawidłowo wyglądająca błona śluzowa wargi dolnej. Rekomendowaną techniką jest linijne, podłużne nacięcie o długości 1-1,5 cm równoległe do granicy czerwieni wargowej i bocznie od linii pośrodkowej ostrzem nr 15 lub soczewkowate wycięcie błony śluzowej o długości $1 \mathrm{~cm}$. Materiał powinien zawierać tylko gruczoły ślinowe w minimalnej ilości 2-3 bez obecności struktur mięśniowych i z innych tkanek. Możliwymi powikłaniami biopsji są niedoczulica wargi, ból, obrzęk i torbiel ślinowa.
\end{abstract}

Słowa kluczowe: zespól Sjögrena, gruczoł wargowy, biopsja.

\section{ABSTRACT}

Introduction. Labial minor salivary gland biopsy is applied for the diagnosis of Sjögren syndrome (SS). The microscopic confirmation of SS is based on the presence of focal lymphocytic sialadenitis (FLS) with a focus score $\geq 1$ per $4 \mathrm{~mm}^{2}$ of glandular tissue.

Aim. The aim of this study was to present the authors' experience and recommendations on taking labial salivary gland biopsies with respect to their histologic criteria, surgical technique, complications, and their usefulness for diagnostic procedures.

Conclusions. The most recommended site is the normal looking mucosa of the lower lip. The recommended technique is a 1.0 to $1.5 \mathrm{~cm}$ linear, horizontal incision of the mucosa parallel to the vermillion border and lateral to the midline with the tip of a 15 scalpel or a $1 \mathrm{~cm}$ lenticular excisional biopsy of the mucosa. The tissue specimens should include only salivary glands with a minimum number of 2-3 glands and without muscular or other tissues. The possible complications of biopsy are lip numbness, pain, swelling or mucocele.

Keywords: Sjögren syndrome, labial salivary gland, biopsy.

\section{Wstęp}

Biopsja wargowych gruczołów ślinowych jest wykorzystywana w diagnostyce chorób tkanki łącznej, takich jak zespół Sjögrena (SS), sarkoidoza, amyloidoza oraz chłoniaków MALT, występujących w przebiegu SS. Metoda ta charakteryzuje się wysoką czułością i swoistością i jest uważana za złoty standard $w$ diagnostyce SS. Według ujednoliconych i zaakceptowanych w 2016 roku przez European League Against Rheumatism (EULAR) kryteriów diagnostycznych pierwotnego SS pozytywny wynik histopatologiczny wargowych gruczołów ślinowych, potwierdzający obecność w tkance gruczołowej jednego lub więcej ogniskowych nacieków limfocytarnych określanych jako focal lymphocytic sialadenitis (FSL), wiąże się z przyznaniem 3 punktów do ważonej sumy wybranych kryteriów serologicznych, klinicznych i histopatologicznych spośród ogólnej sumy 4 koniecznej do 
rozpoznania SS. Podobną wartością diagnostyczną charakteryzuje się również dodatni wynik przeciwciał SSA/SSB. Pozostałe kryteria, takie jak dodatni wynik testu Schirmera lub dodatni wynik badania sialometrycznego, uprawniają do przyznania 1 punktu do ważonej sumy kryteriów rozpoznania SS. Biopsja wargowych gruczołów ślinowych jest obiektywnym kryterium i wobec aktualnych wytycznych diagnostycznych jej rola będzie systematycznie wzrastała. Jest procedurą mało inwazyjną, możliwą do przeprowadzenia w warunkach ambulatoryjnych i obarczoną niewielkim procentem powikłań pozabiegowych. Jednak pomimo wysokiej wartości diagnostycznej jest zabiegiem nadal rzadko wykonywanym i pomijanym głównie z powodu braku opracowanych i zaakceptowanych standardów dotyczących techniki chirurgicznej [1-5].

\section{Cel}

Celem pracy jest przedstawienie $\mathrm{i}$ omówienie techniki chirurgicznej i własnych rekomendacji dla wykonywania biopsji wargowych gruczołów ślinowych u pacjentów z SS mające na celu zapewnienie najwyższej wartości diagnostycznej biopsji i zminimalizowania jej możliwych powikłań.

\section{Uwarunkowania anatomiczne}

Wykonywanie biopsji gruczołów wargowych jest rekomendowane nie tylko ze względu na swoją czułość i swoistość, które szacowane są odpowiednio na $86,7 \%$ i $97,4 \%$, ale także ze względu na łatwą dostępność gruczołów, które w dużych ilościach rozmieszczone są powierzchownie $w$ obrębie warstwy podśluzówkowej [6]. Miejscem preferowanym jest boczna i wewnętrzna powierzchnia wargi dolnej. Należy unikać okolicy centralnej wargi, która jest uważana za strefę ubogogruczołową i wiąże się z ryzykiem pozyskania niewystarczającej ilości materiału tkankowego. Przy wykonywaniu biopsji niezwykle ważne jest uwzględnienie uwarunkowań anatomicznych, jakie występują w sąsiedztwie gruczołów wargowych, a zwłaszcza przebiegu końcowych gałązek nerwu bródkowego. Uszkodzenie zakończeń nerwowych może doprowadzić do czasowej lub stałej niedoczulicy wargi, która jest uważana za główne i najpoważniejsze powikłanie po zabiegowe. Częstość tego powikłania jest $w$ literaturze szacowane na $6 \%$, ale różni się w zależności od stosowanej techniki chirurgicznej [7]. Rozbieżne są także dane dotyczące odwracalności i czasu trwania niedoczulicy. Może mieć ona charakter przejściowy i przemijający lub przybierać postać trwałego i nieodwracalnego uszkodzenia neurologicznego. Uszkodzeniu zakończeń ner- wowych sprzyja bliskość anatomiczna gruczołów wargowych i występująca u części pacjentów anomalia związana z obecnością dodatkowych rozgałęzień nerwu bródkowego i gęstej sieci nerwowej. W celu przeciwdziałania wystąpieniu tego powikłania zaleca się stosowanie powierzchownych cięć, nienaruszających przebiegu mięśnia okrężnego ust oraz zapewnienie jak najlepszej widoczności pola zabiegowego dla właściwej identyfikacji struktur anatomicznych. Rekomendowane jest też użycie lup zabiegowych. Biopsja wycięciowa i wycinkowa gruczołów wargowych nie różnią się statystycznie w częstości uszkodzenia zakończeń nerwowych. Większe znaczenie na wystąpienie tego powikłania mają długość cięcia i jego głębokość. Krótsze cięcia wiążą się z mniejszym ryzykiem niedoczulicy, ale nie zawsze zapewniają właściwy wgląd w pole zabiegowe i możliwość pobrania wystarczającej ilości gruczołów. Naszym zdaniem długość cięcia od 1-1,5 cm jest dogodna z punktu widzenia techniki chirurgicznej i bezpieczeństwa dla pacjenta. Dłuższe cięcia od 3-4 cm w istotny sposób narażają pacjenta na możliwość uszkodzenia zakończeń nerwowych. Pozostałe uwarunkowania anatomiczne mają mniejszy wpływ na wystąpienie powikłań zabiegowych. Uszkodzenie naczyń krwionośnych powoduje wystąpienie w okresie po zabiegu krwiaków i podbiegnięć krwawych, które zwykle ulegają w ciągu kilku dni samoistnemu wchłonięciu. Innym możliwym powikłaniem jest powstanie zmian o charakterze mucoceli, które są wynikiem uszkodzenia przyległych wargowych gruczołów ślinowych, które nie są pobierane do badania histopatologicznego lub ich przewodów wyprowadzających. Mucocele rozwijają się w mechanizmie wynaczynienia i najczęściej są wynikiem przekłucia gruczołu lub jego przewodu podczas szycia. Przeciwdziałaniem wystąpienia tego powikłania jest dokładna identyfikacja gruczołów wargowych i usuwanie wszystkich gruczołów ślinowych z najbliższej okolicy cięcia i szycia.

\section{Wartość diagnostyczna uzyskanego materiału}

Nadrzędnym celem wykonywania biopsji wargowych gruczołów ślinowych w diagnostyce SS jest uzyskanie wystarczającej ilości najbardziej reprezentatywnego i wartościowego pod względem histologicznym materiału tkankowego. FSL jest określane jako ognisko zawierające 50 lub więcej limfocytów w okolicy prawidłowo wyglądającego zrazika gruczołowego w obszarze płata gruczołu, którego przewód wyprowadzający nie wykazuje zwężenia. FSL może występować w obszarze okołoprzewodowym lub okołonaczyniowym. FSL na- 
leży odróżnić od nacieku niespecyficznego tzw. nonspecific sialadenitis (NSL), dla którego charakterystyczna jest atrofia gruczołów, zwężenie przewodów wyprowadzających, nasilone włóknienie oraz nacieki zawierające limfocyty i makrofagi. Występowanie FSL jest oceniane i następnie przeliczane na $4 \mathrm{~mm}^{2}$ materiału tkankowego. Na tej podstawie określany jest też score, którego wartość równa lub większa niż 1 jest uznawana za dodatni wynik biopsji i uprawnia do przyznania 3 punktów w kryteriach diagnostycznych SS [8,9]. Należy dążyć do pobierania wyłącznie gruczołów wargowych, tak aby uzyskany tą drogą i przygotowany preparat histologiczny był pozbawiony elementów $z$ innych tkanek, jak tkanka mięśniowa czy tkanka łączna. Bardziej wartościowy diagnostycznie jest mniejszy objętościowo, ale zawierający wyłącznie gruczoły wargowe materiał niż materiał większy objętościowo, ale zawierający głównie elementy pozagruczołowe. Dodatkową zaletą takiej metody chirurgicznej jest zminimalizowanie ryzyka uszkodzenia zakończeń nerwowych. Kluczowe jest dobre oświetlenie pola zabiegowego i hemostaza, które umożliwiają właściwą identyfikację gruczołów wargowych i ich selektywne wycięcie. Kolejną niezwykle istotną kwestią jest liczba uzyskiwanych w wyniku biopsji gruczołów. Rekomendowaną wielkością materiału tkankowego jest $8 \mathrm{~mm}^{2}[10,11]$. Ideałem jest także pobieranie gruczołów wargowych z kilku różnych poziomów $w$ obrębie pola zabiegowego [12]. Część klinicystów uważa za reprezentatywną i wystarczającą ilość 4 gruczołów. Należy mieć jednak świadomość, że uzyskanie takiej liczby gruczołów jest często technicznie niemożliwe lub istotnie zwiększa ryzyko powikłań. W przebiegu SS dochodzi często do atrofii gruczołów, zwężenia ich przewodów wyprowadzających i nasilonego włóknienia. Obecność FLS powinna być oceniana w sąsiedztwie niezmienionego komponentu gruczołowego. W trakcie wykonywania biopsji nie ma możliwości makroskopowej oceny gruczołów i rozróżnienia tkanki gruczołowej zmienionej od prawidłowej. Należy zachować równowagę pomiędzy dążeniem do uzyskania jak najbardziej reprezentatywnej próbki, a możliwościami technicznymi. W naszej ocenie uzyskanie wycinka zawierającego 3-4 gruczołów jest wystarczające i reprezentatywne. Dobrym sposobem zwiększenia wartości diagnostycznej materiału jest pobranie 2-3 niezależnych skupisk gruczołów w obrębie tego samego nacięcia. Mogą one pochodzić z przeciwległych biegunów lub brzegów pola zabiegowego. Zależy to jednak od indywidualnej dla pacjenta gęstości rozmieszczenia gruczołów wargowych [11-13].
Biopsja wargowych gruczołów ślinowych w odróżnieniu od biopsji ślinianek przyusznych i podjęzykowych nie jest polecana do monitorowania efektywności leczenia. Wynika to z faktu, że jest bardzo czuła na stosowane w okresie jej wykonywania leki przeciwzapalne i immunosupresyjne, które mogą zmniejszać ilość i wielkość nacieków limfocytarnych, stanowiących o potwierdzeniu występowania FLS i tym samym o pozytywnym rozpoznaniu SS. Nie ma właściwie możliwości wielokrotnego powtarzania biopsji wargowych gruczołów wargowych celem monitorowania jej progresji i oceny efektywności leczenia. Biopsja powinna być wykonywana wyłącznie w celach diagnostycznych, kiedy pacjent nie przyjmuje jeszcze żadnych leków immunosupresyjnych i sterydowych. W okresie wykonywania biopsji pacjent powinien także unikać stosowania płukanek sterydowych $[8,13]$.

\section{Technika chirurgiczna}

Biopsja może być wykonywana w warunkach ambulatoryjnych w znieczuleniu miejscowym. Preferowane jest stosowanie do znieczulenia nasiękowego $1 \%$ lidocainy $z$ dodatkiem adrenaliny $w$ stężeniu 1:100000 w ilości $1 \mathrm{ml}$. Wprowadzenie środka znieczulającego bezpośrednio do warstwy podśluzówkowej poprawia oddzielenie gruczołów wargowych od innych struktur anatomicznych. Stają się one lepiej widoczne, tatwiejsze w odpreparowaniu i wycięciu. Należy wprowadzić środek znieczulający bezpośrednio do warstwy podśluzówkowej. Dodatek adrenaliny jest także pożądany ze względu na zmniejszone krwawienie. W trakcie nacięcia i preparowania gruczołów warga powinna być wywinięta i nieznacznie napięta poprzez ucisk operatora lub osoby asystującej. Zmniejsza to krwawienie, poprawia widoczność i orientację w polu zabiegowym i eksponuje gruczoły wargowe. Opisywane w piśmiennictwie różnego rodzaju haki i stabilizatory, które uciskają, poszerzają i utrzymują dostęp do pola zabiegowego $w$ naszej opinii mogą być źródłem otarć, wybroczyn i uszkodzeń śluzówki w okresie pozabiegowym. Wymagają one uprzedniego stosowania maści lub kremów natłuszczających i ochronnych. Podobny efekt można uzyskać stosując delikatny, ale stały ucisk i wywinięcie dolnej wargi. Cięcie wykonuje się na wewnętrznej powierzchni wargi w jej bocznym odcinku na wysokości dolnego kła i zębów przedtrzonowych. Do cięcia używa się ostrza nr 15. W piśmiennictwie opisywane są różne rodzaje cięć do wykonywania biopsji wargowych gruczołów wargowych. Stosuje się cięcia linijne równoległe i prostopadłe do przebiegu wargi, cięcia w kształcie ostrza, eliptyczne, 
półkoliste i soczewkowate. Kształt i głębokość cięcia determinuje także wycięciowy lub wycinkowy charakter biopsji [14-17]. Autorzy preferują cięcia linijne o długości 1-2 cm równoległe do granicy wargi oraz cięcia soczewkowate o długości 1-1,5 cm również równoległe do granicy wargi. Cięcia linijne zapewniają dobrą adaptację brzegów rany, szybsze gojenie i mniejsze włóknienie pozabiegowe. Przez krótki okres po zabiegu pacjent może odczuwać nieznaczne zgrubienie w miejscu cięcia. Dzięki równym brzegom rany i dobrej ich adaptacji blizna nie jest widoczna i może przybierać postać nieznacznego i przejściowego zgrubienia. Gorsza jest natomiast widoczność pola zabiegowego i identyfikacja gruczołów. Przy niewielkiej gęstości gruczołów uzyskanie wystarczającej ich liczby poprzez linijne nacięcie może być technicznie trudniejsze. Natomiast gruczoły gęsto i powierzchownie rozmieszczone mogą być łatwo wycięte. Takie nacięcie zawsze wiąże się $z$ wycinkowym charakterem biopsji. Celem lepszej identyfikacji gruczołów można delikatnie podpreparować i rozchylić oba brzegi rany oraz wywinąć wargę. Drugą rekomendowaną przez nas techniką jest wykonanie cięcia soczewkowatego o długości 1-1,5 cm i maksymalnej wysokości $0,5 \mathrm{~cm}$ oraz delikatnym i płytkim wycięciu pokrywająym błonę śluzową. Często gruczoły wargowe znajdują się pod wycinanym fragmentem błony śluzowej. Technika ta ma więc postać płytkiej biopsji wycięciowej, ograniczonej tylko do warstwy śluzówkowej. Dodatkowo po usunięciu warstwy śluzówkowej można pobrać głębiej położone gruczoły. Technika ta zapewnia doskonałą widoczność pola zabiegowego i identyfikację gruczołów od innych struktur anatomicznych. Jest szczególnie przydatna w przypadku małej gęstości gruczołów i trudności z ich pozyskaniem. Taki rodzaj cięcia poszerza pole zabiegowe, tworzy automatycznie różne poziomy w obrębie tego samego miejsca biorczego. Wiąże się z nieznacznie większą utratą tkanek i gorszą adaptacją brzegów rany. Oba rodzaje cięć mogą powodować podobne powikłania pozabiegowe. Mają one zwykle krótki, kilkudniowy przebieg. Może wystąpić nieznaczny ból i obrzęk w miejscu cięcia, uczucie ściągnięcia, swędzenia i pieczenia wargi, kłopoty z jedzeniem i mówieniem. Wynikiem uszkodzenia naczyń krwionośnych może być krwiak lub wybroczyna. Wczesnym powikłaniem jest także rozejście się brzegów rany. Konsekwencją opóźnionego lub powikłanego gojenia może być blizna przerostowa, keloid, zwiększone i trwale się utrzymujące zgrubienie wargi oraz powstanie ziarniniaka. Najpoważniejszym możliwym powikłaniem jest przejściowa lub trwała niedoczulica wargi. Miejsce po biopsji powinno być zabezpieczone pojedynczymi szwami nieresorbowalnymi. Wskazania pozabiegowe dla pacjenta nie odbiegają istotnie od postępowania po innych zabiegach chirurgicznych w jamie ustnej [18-20].

Biopsję wargowych gruczołów ślinowych przeprowadza się wyłącznie w celach diagnostycznych, $w$ celu potwierdzenia rozpoznania klinicznego lub w przypadku niejednoznacznych dla SS objawów klinicznych i serologicznych. Materiał tkankowy musi zawierać dostateczną ilość gruczołów bez dodatkowych struktur pozagruczołowych. Należy unikać głębokich cięć w centralnej części wargi. Kluczowe są identyfikacja gruczołów, dobre oświetlenie pola zabiegowego, hemostaza, które zmniejszają ryzyko uszkodzenia zakończeń nerwowych. Rekomendowane są cięcia linijne lub płytka biopsja wycięciowa po uprzednim soczewkowatym nacięciu. Możliwe powikłania są krótkotrwałe i nie różnią się istotnie od powikłań charakterystycznych dla innych zabiegów chirurgicznych w jamie ustnej.

\section{Oświadczenia}

Oświadczenie dotyczące konfliktu interesów

Autorzy deklarują brak konfliktu interesów w autorstwie oraz publikacji pracy.

\section{Źródła finansowania}

Autorzy deklarują brak źródeł finansowania.

\section{Piśmiennictwo}

[1] Shiboski CH, Shiboski SC, le Seror R, Criswell LA, Labetoulle M, Lietman TM, Rasmussen A, Scofield H, Vitali C, Bowman SJ, Mariette X, and the International Sjögren's Syndrome Criteria Working Group. 2016. American College of Rheumatology/European League Against Rheumatism Classification Criteria for Primary Sjögren's Syndrome. A Consensus and Data-Driven Methodology Involving Three International Patient Cohorts. Ann Rheum Dis. 2017;76(1):9-16.

[2] Franceschini F, Cavazzana I, Andreoli L, Tincani A. The. 2016 classification criteria for primary Sjogren's syndrome: what's new? BMC Medicine. 2017;31(15):69.

[3] Błochowiak KJ, Trzybulska D, Olewicz-Gawlik A, Sikora J, Nowak-Gabryel M, Kocięcki J, Witmanowski $\mathrm{H}$, Sokalski J. Levels of EGF and VEGF in patients with primary and secondary Sjögrn's syndrome. Adv Clin Exp Med. 2018;27(4):455-461.

[4] Błochowiak KJ, Olewicz-Gawlik A, Trzybulska D, Nowak-Gabryel M, Kocięcki J, Witmanowski H, Sokalski J. Serum ICAM-1, VCAM-1 and E-selectin levels in patients with primary and secondary Sjögren's syndrome. Adv Clin Exp Med. 2017;26(5):835-842.

[5] Błochowiak K, Olewicz-Gawlik A, Polańska A, Nowak-Gabryel M, Kocięcki J, Witmanowski H, Sokalski J. Post Derm Alerg. 2016;33:23-27. 
[6] Giovelli RA, Santos MC, Serrano E, Valim V. Clinical characteristics and biopsy accuracy in suspected cases of Sjögren's syndrome reffered to labial salivary gland biopsy. BMC Musculoskeletal Disorders. 2015;16:30.

[7] Delli K, Vissink A, Spijkervet FK. Salivary gland biopsy for Sjögren's syndrome. Oral Maxillofac Surg Clin North Am. 2014;26(1):23-33.

[8] Kim J, Sun D, Ozl R, Graderbeck T, Birnbaum J, Akpek EK, Baer AN. A validated method of labial minor salivary gland biopsy for the diagnosis of Sjögren's syndrome. Laryngoscope. 2016;126(9):2041-2046.

[9] Fox RI. Sjögren's syndrome. Lancet. 2005;366(9482): 321-331.

[10] Fox RI. Standardisation of labial salivary gland biopsies in Sjögren's syndrome. Ann Rheum Dis. 2017 Jul;76(7):1159-1160.

[11] Fisher BA, Jonsson R, Daniels $T$, Bombardieri $M$, Brown RM, Morgan P, Bombardieri S, Ng WF, Tzioufas AG, Vitali C, Shirlaw P, Haacke E, Costa S, Bootsma $H$, Devauchelle-Pensec V, Radstake TR, Mariette X, Richards A, Stack R, Bowman SJ, Barone1 F, on behalf of the Sjögren's histopathology workshop group (appendix) from ESSENTIAL (EULAR Sjögren's syndrome study group) et al. Standardisation of labial salivary gland histopathology in clinical trials in primary Sjögren's syndrome. Ann Rheum Dis. 2017;76(7):1161-1168.

[12] Sarioğlu S, Küçük Ŭ, Cetin P, Sari I, Bĭrlĭk AM. Minor salivary gland evaluation: Sjögren's syndrome. Turk J Med Sci. 2016;46:63-65.

[13] Varela-Centelles P, Sanchez-Sanchez M, Seoane J. Lip biopsy for the diagnosis of Sjögren's syndrome: beware of the punch. Int J Oral Maxillofac Surg. 2014;43(1):127-130.

[14] Gorson KC, Ropper AH. Positive salivary gland biopsy, Sjögren's syndrome and neuropathy: clinical implications. Muscle. Nerve. 2003;28(5):553-560.

[15] Berquin K, Mahy P, Weynand B, Reychler H. Accessory or sublingual salivary gland biopsy to assess systemic disease: a comparative retrospective study. Eur Arch Otorhinolaryngol. 2006;263(3):233-236.
[16] Saruhano A, Ati M, Ergun S, Ofluo?lu D, Tanyeri H. Comparison of two different labial salivary gland biopsy incision techniques: A randomized clinical trial. Med Oral Patol Oral Cir Bucal. 2013;18(6):e851 -e855.

[17] Collela G, Cannavale R, Vicidomini A, Intro A. Salivary gland biopsy: a comprehensive review of techniques and related complications. Rheumatology. 2010;49(11):2117-2121.

[18] Soyfoo MS, Catteau X, Delporte C. Parotid gland biopsy as an additional diagnostic tool for supporting the diagnosis of Sjögren's syndrome. Int J Rheumatol. 2011;2011:302527.

[19] Pijpe J, Kalk WW, van der Wal JE, Vissink A, Kluin Ph.M, Rodenburg JL, Bootsma H, Kallenberg CG, Spijkervet FK. Parotid gland biopsy compared with labial biopsy in the diagnosis of patients with primary Sjögren's syndrome. Rheumatology(Oxford) 2007;46(2):335-341.

[20] Guellec D, Cornec D, Jousse-Joulin S, Marhadour T, Marcorelles P, Pers JO, Saraux A, Devauchelle-Pensec $V$. Diagnostic value of labial minor salivary gland biopsy for Sjögren's syndrome: A systematic review. Autoimmunity Reviews. 2013;12:416-420.

Zaakceptowano do edycji: 2018-10-16 Zaakceptowano do publikacji: 2018-12-05

\author{
Adres do korespondencji: \\ Katarzyna Błochowiak \\ Katedra i Klinika Chirurgii Stomatologicznej \\ i Periodontologii \\ Uniwersytet Medyczny im. Karola Marcinkowskiego \\ ul. Bukowska 70, 60-812 Poznań \\ tel.: 608836850 \\ e-mail: kasia@naszdentysta.com.pl
}

